\title{
The bush dog Speothos venaticus: area requirement and habitat use in cultivated lands
}

\author{
Edson S. Lima, Maria Luisa S. P. Jorge \\ Rodrigo S. P. Jorge and Ronaldo G. Morato
}

\begin{abstract}
We radio-tracked a pack of bush dogs Speothos venaticus (7-10 individuals) near Água Boa in Mato Grosso, Brazil, for 18 months to investigate their use of habitat in cultivated land. The pack's home range was $709 \mathrm{~km}^{2}$ (fixed-kernel 95\%), which exceeds estimates of home range for the largest Neotropical carnivore, the jaguar Panthera onca. Of the 245 locations where the dogs were recorded $95 \%$ were within native vegetation (savannah and forest), even though these habitats comprised only $34 \%$ of the pack's home range. This indicates a preference for native vegetation, and this was reinforced by composition analysis of habitat use, which showed that the pack used savannah and forest more than expected and cultivated areas less than expected. Analysis of activity showed that the bush dogs were moving quickly in more than half of the locations in cultivated areas, foraging in most savannah locations and resting in most forest locations. Our results indicate that bush dogs can live in areas with a high proportion of cultivated land (66\%), possibly because of the structural connectivity of the landscape $(80 \%$ of the native habitat is within a single patch). However, their home range appears to be inflated compared to that of other carnivores, which may have a negative effect on the species in the long term.
\end{abstract}

Keywords Cerrado, compositional analysis, connectivity, Focal Patch, fragmentation, habitat use, Neotropics, radiotelemetry

This paper contains supplementary material that can be found online at http://journals.cambridge.org

\section{Introduction}

$\mathrm{R}$ eduction and isolation of native habitats are threats to Rbiodiversity (Fahrig, 2003), and understanding how species respond to landscape change is fundamental to

Edson S. Lima, Maria Luisa S. P. Jorge* (Corresponding author), Rodrigo S. P. Jorge $\dagger$ and Ronaldo G. Morato $\dagger$ i Instituto Pró-Carnívoros, Av. Horácio Neto 1030, CEP 12945-000, Atibaia, São Paulo, Brazil

E-mail malu.jorge@vanderbilt.edu

*Also at: Earth \& Environmental Sciences, Vanderbilt University, PMB 351805, 2301 Vanderbilt Place, Nashville, TN 37235-1805, USA

$\dagger$ Also at: Instituto Chico Mendes de Conservação de Biodiversidade, Brasília, Brazil ¥Also at: Centro Nacional de Pesquisa e Conservação de Mamíferos Carnívoros, Atibaia, São Paulo, Brazil

Received 2 April 2013. Revision requested 13 June 2013.

Accepted 29 January 2014. First published online 9 September 2014. improving the effectiveness of conservation efforts (Knowlton \& Graham, 2010). Home ranges, or the spatial distribution of animals within a population, are thought to reflect the distribution of preferred resources in the landscape (Mitchell \& Powell, 2004). In human-modified landscapes home ranges may also reflect the ability of animals to move around the heterogeneous landscape to reach their preferred patches. Such ability is both landscape- and species-dependent. Animals may increase their home ranges in response to a reduction of their preferred habitats, as has been observed in bobcats Lynx rufus (Tucker et al., 2008) and raccoons Procyon lotor (Beasley \& Rhodes, 2010), if there is high structural connectivity between preferred patches or if the animals are able to cross the surrounding matrix to move between patches (high functional connectivity, sensu Tischendorf \& Fahrig, 2000). Alternatively, animals may reduce their home ranges, as seen among Eurasian red squirrels Sciurus vulgaris (Verbeylen et al., 2009) and European pine martens Martes martes (Mergey et al., 2011), if structural and functional connectivity are low. Evaluating how each species responds to distinct landscape contexts is essential for better conservation planning and to ensure long-term persistence of a diverse array of native species in the face of increasingly human-dominated heterogeneous landscape scenarios.

The bush dog Speothos venaticus is an elusive Neotropical canid categorized by the Brazilian Ministry of Environment as Threatened (MMA, 2003), and as Near Threatened on the IUCN Red List (DeMatteo et al., 2011). Information on the spatial needs and habitat preferences of bush dogs is scarce because it is difficult to record and monitor the species in the wild. In a fragmented landscape in northern Mato Grosso, Brazil, Michalski \& Peres (2007) and Michalski (2010) recorded bush dogs only twice during a 2-year interview programme and twice during almost 5,000 camera-trap days. In an area of continuous forest in southern São Paulo, Brazil, a pair of bush dogs was recorded for the first time after 4,818 camera-trap days (Beisiegel, 2009). Based on a macro-scale analysis DeMatteo \& Loiselle (2008) suggested that bush dogs were more likely to occur in pristine habitats $(80 \%$ of records were in pristine habitats). At the local scale Michalski \& Peres (2007), Michalski (2010) and Beisiegel (2009) reinforced the same hypothesis with records in patches $>1,000$ ha and in continuous forest. In contrast, de Oliveira (2009) recorded bush dogs in habitats of varying quality. These studies indicate 


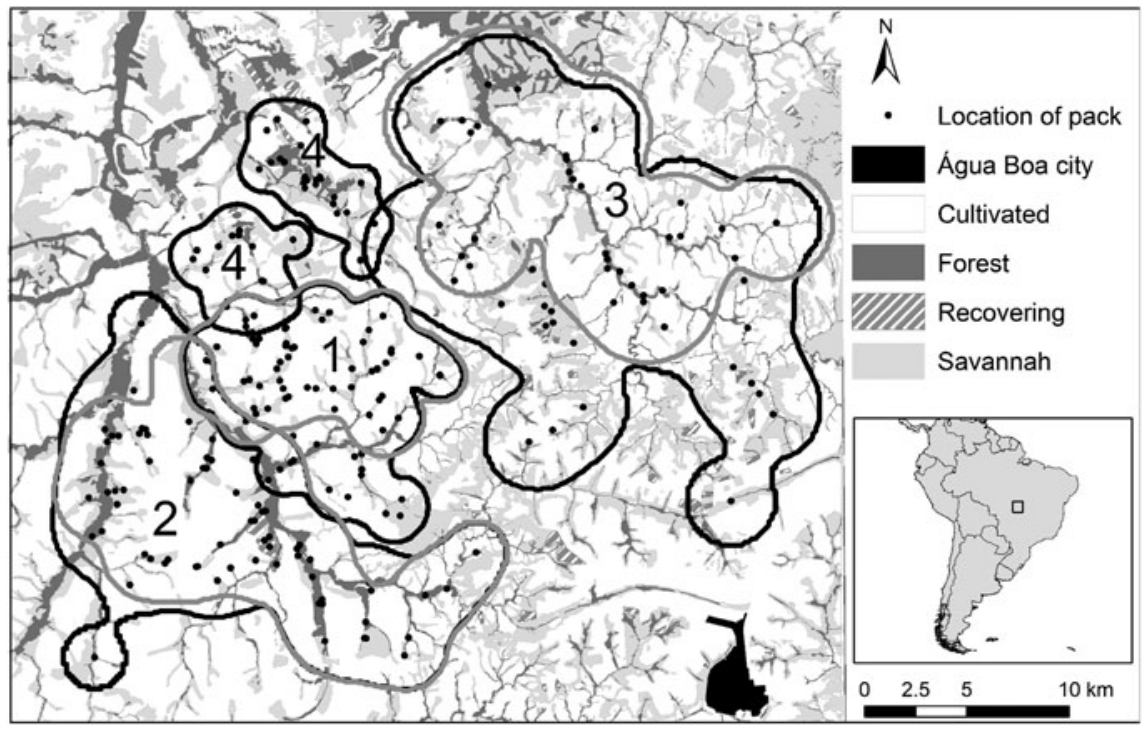

FIG. 1 Habitat types, locations and sub-areas (fixed-kernel 95\%) used by a pack of bush dogs Speothos venaticus (7-10 individuals) in the Água Boa district, Mato Grosso, Brazil, during May 2008-December 2009. The percentage of native habitat in the region is low ( $34 \%$ of the total area) but structural connectivity is high (80\% of the native habitat is connected within a single patch). Most locations fall within native habitats (forest or savannah). Each area was visited for 1-2 months and then revisited after c. 1 year, in a rotational or semi-nomadic movement pattern. Areas are numbered chronologically, with black lines indicating first use and grey lines indicating second use.

that bush dogs have a preference for native habitats but can also be found in human-modified landscapes.

Knowledge of the bush dog's area requirements is essential for improved estimates of population density and size. Two early attempts to estimate the species' area requirements used a correlation between body size and home range of other canid species. Silveira et al. (1998) estimated a home range of $4.72 \mathrm{~km}^{2}$ per individual. Beisiegel (1999) refined the correlation with a correction factor for dietary specialization and estimated a home range of $25 \mathrm{~km}^{2}$ per individual. More recently Lima et al. (2012) reported a home range of $140 \mathrm{~km}^{2}$ (95\% fixed kernel) for a pack of $3-7$ bush dogs in a relatively undisturbed area (86\% native habitat), based on radio-telemetry data, which is close to the estimate of Beisiegel (2009). Nevertheless, information on how the bush dog's area requirements change with reduction and fragmentation of native habitats is still lacking, and such information is critical for improved estimates of population densities and sizes, and identification of priority habitats for conservation of the species.

The Cerrado is Brazil's second largest biome (Klink \& Machado, 2005) and it encompasses $25 \%$ of the bush dog's distribution (K. Ferraz et al., unpubl. data). Since the 1960 s the Cerrado has been converted for monocultures of soya bean, rice and wheat, and cattle ranches, and only $20 \%$ of its native vegetation remains intact (Klink \& Machado, 2005). Here we report our findings on the area requirements and habitat use of a pack of bush dogs tracked by radiotelemetry in an area of the Cerrado with only $34 \%$ of native habitat but with high structural connectivity $(80 \%$ of the native habitat is within a single patch). Our main objective is to report on how this elusive species of carnivore is adapting in a human-modified landscape and to aid understanding of how movement and use of space by carnivores are affected by habitat reduction.

\section{Study area}

The study was conducted at the headwaters of the Sete de Setembro River, c. $15 \mathrm{~km}$ north-west of Âgua Boa municipal district in the state of Mato Grosso, Brazil (Fig. 1). The economy of Água Boa is based on agriculture and cattle, and since 1970 a significant portion of its native vegetation has been cleared for cultivation. Native vegetation still remains in some areas, especially in swampy or elevated terrain and close to rivers (under the Brazilian Conservation Act, n. $4.771 / 1965$ and n. 12.651/2012, native vegetation on river margins on private lands must be preserved, with distances depending on river width). The region is within the Brazilian Cerrado biome and the native vegetation is predominantly savannah (all native grassland formations, including swampy grassland, dry grassland, shrubby grassland, and grassland with scattered short trees), with patches of forest (gallery, dry and valley forests; see Oliveira-Filho \& Ratter (2002) for descriptions and pictures of all distinct Cerrado vegetation types). In the 2010 population census Água Boa had a rural population of 4,097 people, at a density of c. $0.5 \mathrm{~km}^{-2}$ (IBGE, 2013). In 2006 there were estimated to be 280,797 cows in the municipality $\left(38 \mathrm{~km}^{-2}\right.$; IBGE, 2013). The climate is characterized by two distinct seasons: rainy (October-March) and dry (April-September), with mean annual rainfall of c. 1,600 mm (Nimer, 1989) and no seasonal flooding.

\section{Methods}

\section{Capture and monitoring}

On 25 May 2008 we captured a pack of bush dogs (Supplementary Material 1) comprising 10 individuals: two dominant adults (one male, one female), three young adults 
TABLE 1 Home range of a bush dog Speothos venaticus pack (7-10 individuals) radio-tracked in Água Boa district, east Mato Grosso, Brazil (Fig. 1) during May 2008-December 2009, with minimum convex polygon (MCP) and fixed-kernel estimates.

\begin{tabular}{|c|c|c|c|c|c|c|}
\hline & \multirow[b]{2}{*}{ No. of locations } & \multirow[b]{2}{*}{ No. of individuals } & \multirow{2}{*}{$\frac{\mathrm{MCP}^{1}\left(\mathrm{~km}^{2}\right)}{95 \%}$} & \multicolumn{3}{|c|}{ Fixed kernel ${ }^{2}\left(\mathrm{~km}^{2}\right)$} \\
\hline & & & & $95 \%$ & $75 \%$ & $50 \%$ \\
\hline May 2008-Dec 2009 & 245 & $7-10$ & 544.6 & 708.8 & 379.8 & 189.3 \\
\hline July 2008-July 2009 & 160 & $9-10$ & 546.7 & 702.2 & 388.8 & 204.0 \\
\hline
\end{tabular}

${ }^{1} \mathrm{MCP}$ with $95 \%$ of the most central locations (5\% outliers excluded)

${ }^{2}$ Grid cell for the fixed kernel was $100 \times 100 \mathrm{~m}(10 \times 10 \mathrm{~m}, 50 \times 50 \mathrm{~m}$ and $150 \times 150 \mathrm{~m}$ were tested, yielding similar results $)$

(one male, two females) and five juveniles (four males, one female).

All dogs were sedated with an intramuscular injection of $5 \mathrm{mg}$ per kg tiletamine hydrochloride and zolazepam hydrochloride (Zoletil 50, Virbac, Brazil) for morphometric measurements and estimation of age (through analysis of teeth development). The adults and young adults were fitted with 164-MHz VHF radio collars (Advanced Telemetry Systems, Isanti, USA) of an optimum design for the species (DeMatteo \& Kochanny, 2004). Each collar was equipped with an activity switch. To determine the age of each animal we examined their size, fur colour, and teeth (type, quantity and quality). For full information on the handling and release of the animals see Supplementary Material 1.

We tracked the bush dogs for 81 weeks, during 25 May 2008-4 December 2009. The pack was monitored from the ground, using a TR4 radio receiver and RA-14 H-directional antenna (Telonics, Mesa, USA). We returned to the area every day to attempt to locate the pack. Geographical coordinates were recorded using a global positioning system (GPS) and in all instances the pack was located by direct observation (i.e. either by visual or auditory contact within $10-20 \mathrm{~m}$ or by den location).

Home range, habitat preferences, and activity patterns by habitat type

Locations from all five collars were considered as a unit (pack location) as the dogs were always within $10-20 \mathrm{~m}$ of each other. Home range was estimated using the fixedkernel method (95, 75 and 50\%; Worton, 1987, 1989; Table 1), using IDL v. 8.2.3 (Exelis Visual Information Solutions, Boulder, USA). The fixed-kernel method needs a smoothing parameter $(h)$ in its calculation, which determines the width of each kernel. In practice, $h$ determines whether a kernel distribution will be more or less detailed (Seaman \& Powell, 1996). The least-squares cross-validation (LSCV), used in this study, is an unbiased method of determining $h$ (Seaman \& Powell, 1996). We also used the deterministic minimum convex polygon (95\%; Mohr, 1947; Hayne, 1949; Table 1) to determine the home range, for comparison with the home ranges of other carnivore species.
To evaluate if habitat use was random relative to availability we used a compositional analysis (Aebischer et al., 1993), with proportions of use and availability logtransformed to eliminate non-independence. Proportions of use were generated from the fixed-kernel utilization distribution rather than direct locations because the utilization distribution quantifies use within the home range with a probabilistic and continuous metric and eliminates concerns about independence between points (Marzluff et al., 2004).

We calculated proportions of different habitat types, using a 2007 Spot satellite image $(2.5-\mathrm{m}$ resolution) of the study area as a reference. The satellite image was acquired from the Secretary of Environment of the state of Mato Grosso. Six categories of habitat were identified, using ArcGIS v. 9.2 (ESRI, Redlands, USA). These were (1) savannah (all native grassland formations, including swampy grassland, dry grassland, shrubby grassland, and grassland with scattered short trees), (2) forest (gallery, dry and valley), (3) cultivated areas (pasture and agricultural crops), (4) recovering vegetation (abandoned cultivated lands with native pioneer species present), (5) urban areas (cities and surroundings), and (6) water bodies. Only three categories were included in the final compositional analysis (savannah, forest, and cultivated lands) because the pack's home range did not encompass urban areas, only $0.03 \%$ of the range comprised recovering vegetation, and there were no locations in water bodies.

We created a resource utilization function (Marzluff et al., 2004), using the Focal Patch extension of ArcView v. 3.2 (ESRI, Redlands, USA), which expresses the correlation between the utilization distribution and the vegetation categories. Finally, we generated a contingency table of level of use (low, medium, high) by vegetation category, and used a $G$-test to test for statistically significant differences in the proportion of use and availability per vegetation type (Supplementary Material 2).

For each location we categorized activity (Supplementary Material 3) as inactive, foraging/moving locally or moving fast, to correlate activity with the habitat types used by the pack. Significant differences between actual and expected frequencies of category of activity were tested using a $G$-test. 


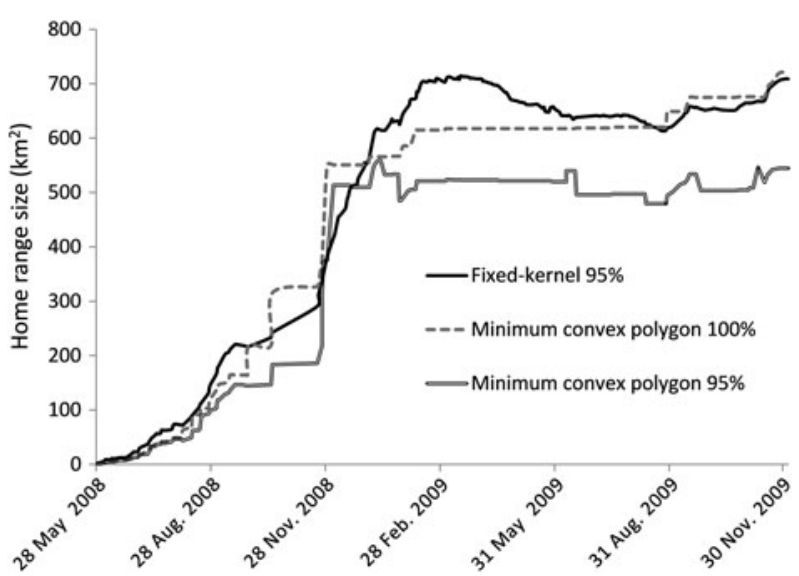

FIG. 2 Cumulative home range size (fixed-kernel 95\%, minimum convex polygon $100 \%$ and $95 \%)$ of a pack of bush dogs (7-10 individuals) in the Água Boa district, Mato Grosso, Brazil (Fig. 1), during May 2008-December 2009. The increase in the fixed-kernel $95 \%$ estimate after January 2009 is probably an effect of sample size.

\section{Results}

We tracked the pack of bush dogs to 245 locations. More than half of the consecutive records $(53 \%, \mathrm{n}=130)$ were made on consecutive days. Nine locations (4\%) were recorded on the same day. Of the remaining locations, $9 \%$ were recorded within 2 days, $14 \%$ within 3 days, $11 \%$ within 4 days, $5 \%$ within 5 days and $2 \%$ within 6 days. Four consecutive locations were recorded at intervals of $>_{9}$ days (10, 16, 18 and 36 days). During these periods we lost track of the pack temporarily (27 September-15 October 2008; 16 October-21 November 2008; 17 June-3 July 2009; 12-22 October 2009). On average, we located the pack 3 days per week. Periods when the pack was recorded on consecutive days lasted 2-6 days (77 periods in total), with 42 2-day periods, 23 3-day periods, seven 4-day periods, three 5-day periods and two 6-day periods.

Home range estimates for the 18 -month study period were $709 \mathrm{~km}^{2}$ (fixed-kernel 95\%; $h_{(\mathrm{LONG}) \mathrm{LSCV}}=1,672 \mathrm{~m}$ and $h_{(\mathrm{LAT}) \mathrm{LSCV}}=2,008 \mathrm{~m}$; grid cell size $\left.=100 \times 100 \mathrm{~m}\right)$ and $545 \mathrm{~km}^{2}$ (minimum convex polygon 95\%; Table 1). From May 2008 to January/February 2009 the home range size increased, with no signs of levelling off (Fig. 2). In February 2009 the home range reached an asymptote as the pack started to move towards areas within the home-range boundaries (Fig. 1). After the period of reproduction (February-April 2009; Area 4, Fig. 1), the pack started returning to areas used previously (Areas 1, 2 and 3, Fig. 1). The increase and posterior decrease in the fixed-kernel 95\% estimate after January 2009 (Fig. 2) is probably an effect of the probabilistic method. Once the pack started to move within the home-range boundaries, the kernel peaks of the fixed-kernel estimate became more accentuated as more locations were included and the fixed-kernel 95\% boundaries

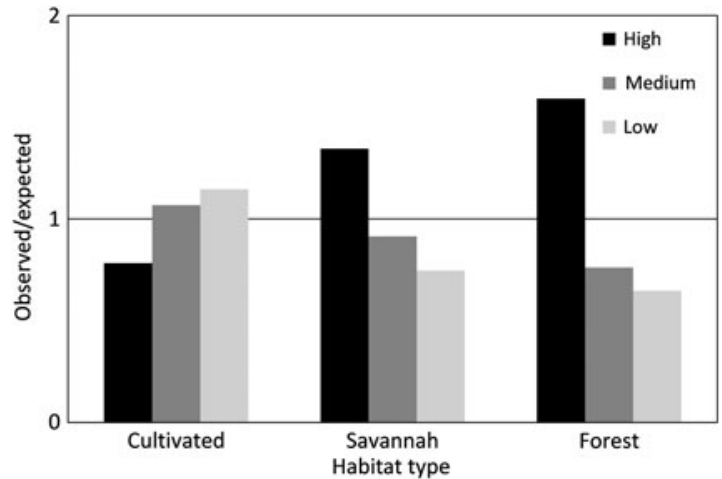

FIG. 3 Compositional analysis of a grid of intensity of use (low, medium, high) vs main habitat types (cultivated lands, forest, savannah). There were significantly more high-use cells than expected in the savannah and forest, and fewer than expected in cultivated lands.

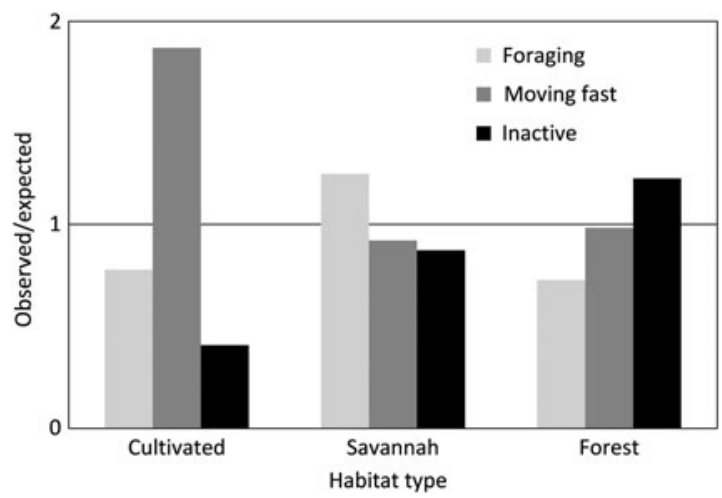

FIG. 4 Compositional analysis of activity pattern (foraging/ moving locally, moving fast, and inactive) vs habitat type (cultivated lands, forest, savannah). At most locations recorded in cultivated lands the animals were moving fast, at most locations in the savannah they were foraging, and at most locations in the forest they were inactive.

decreased. Overall, after 1 year (in May 2009) the pack used the same areas again (Fig. 1), suggesting a pattern of rotational use or semi-nomadic movement.

Although most of the region comprises cultivated land ( $66 \%$ of the pack's home range), the pack predominantly used native vegetation (230 of 245 locations; Fig. 3). A $G$-test of the resource utilization function confirmed this preference, with the pack using forest and savannah habitats significantly more than expected (forest: $G=44.02, \mathrm{df}=2$, $\mathrm{P}<$ o.001; savannah: $G=42.07, \mathrm{df}=2, \mathrm{P}<0.001)$ and cultivated land significantly less than expected $(G=45.82, \mathrm{df}=2$, $\mathrm{P}<$ o.oo1; Fig. 4).

We were able to determine the activity at 237 of the 245 locations ( 89 inactive, 70 foraging/moving locally, and 78 moving fast). Of these, 122 were in savannah, 102 in forest and 13 in cultivated areas. When considered in the context of habitat type (forest, savannah, and cultivated areas) our results showed that foraging/moving locally occurred 
more than expected in savannah, inactive occurred more than expected in forest, and moving fast occurred more than expected in cultivated areas $(G=12.33, \mathrm{df}=4$, $\mathrm{P}=$ 0.015; Fig. 4).

Further details of our results can be found in Supplementary Material 4.

\section{Discussion}

We found that a pack of bush dogs (7-10 individuals) covered an area of $709 \mathrm{~km}^{2}$ over a period of 18 months, which exceeds the estimates of home range for other Neotropical carnivores, such as the jaguar Panthera onca $\left(30-270 \mathrm{~km}^{2}\right.$; Rabinowitz \& Nottingham, 1986; Crawshaw \& Quigley, 1991; Cascelli de Azevedo \& Murray, 2007; Cavalcanti \& Gese, 2009) and the maned wolf Chrysocyon brachyurus (20-130 km²; Dietz, 1984, 1985; de Melo et al., 2007; Jácomo et al., 2009). Our estimate is similar to the largest estimates for the African wild dog Lycaon pictus (210-830 $\mathrm{km}^{2}$; Woodroffe, 2011). African wild dogs usually live in packs that are similar in size to those of bush dogs $(3-15$ individuals; Woodroffe, 2011) but they have larger body sizes (18-36 kg; Sillero-Zubiri et al., 2004) and therefore one would expect that packs of bush dogs would have smaller home ranges.

There is evidence that the large home range of the bush dog pack we studied may be related to the limited area of native habitat, although we acknowledge that inferences from our results are weakened by our sample size of one. In a previous study of bush dogs in a nearby region (Nova Xavantina, Mato Grosso) we estimated the home range of a pack to be c. $140 \mathrm{~km}^{2}$ (fixed-kernel 95\%; 3-7 individuals tracked for 13 months; Lima et al., 2012). For a better comparison between the two estimates, we estimated the home range of the Água Boa pack for the same period (July 2008July 2009; $702.2 \mathrm{~km}^{2}$; Table 1 ). We also corrected our estimate by the number of individuals $\left(70.2 \mathrm{~km}^{2}\right.$ per individual in Água Boa and 3-7 individuals), assuming that home range increases linearly with the number of individuals in a pack. With the corrected estimate, the home range of the Água Boa pack is still 1.5 to 3.5 times that of the pack from Nova Xavantina $\left(210-490 \mathrm{~km}^{2}\right.$ vs $\left.140 \mathrm{~km}^{2}\right)$, considering the same period and number of individuals in both packs. The difference in the amount of native habitat remaining in the two areas may explain the differences in home range sizes. In Nova Xavantina $86 \%$ of the area comprises native savannah and forest, whereas in Água Boa only $34 \%$ of the area comprises native habitats. Both packs preferentially used native habitats (either forest or savannah) and avoided cultivated land. In our study most records of the pack in cultivated land indicated they were passing through quickly, whereas in the forest and savannah they were foraging, eating or resting. These results suggest that the bush dogs from eastern Mato Grosso adjust the size of their home range depending on the availability of native habitat.

It is important to note that towards the end of the study of Lima et al. (2012) three of the seven animals developed hair loss and eventually died (the events suggest the deaths were related to hair loss but parasitological analyses were inconclusive). Hence the smaller home range of the Nova Xavantina pack may have been a result of illness affecting their movement. However, complementary analyses of daily distance moved, and our own observations of both packs, do not support this hypothesis. Both packs behaved and moved similarly, covering similar distances every day (Nova Xavantina: median daily distance $=1,124 \mathrm{~m}$; Água Boa: median daily distance $=974 \mathrm{~m}$ ), using the same habitat types, and killing armadillos at the same rate (on average, every other day), and therefore we believe that the spatial comparison between the two packs is valid. The main difference in the movements of the packs was that the Nova Xavantina pack returned to a central area every 2 months (Lima et al., 2012; Fig. 3) whereas the Água Boa pack used areas on a rotating basis (Fig. 1), possibly because resources are more widespread spatially in the Água Boa region.

Studies of space utilization and habitat fragmentation show that some mammals respond to fragmentation by reducing their home range (e.g. Eurasian red squirrels, Verbeylen et al., 2009; European pine martens, Mergey et al., 2011) and others by home range expansion (e.g. bobcats, Tucker et al., 2008; raccoons, Beasley \& Rhodes, 2010). Our findings indicate that the bush dogs in Água Boa are in the second category and expand their home range in response to a decrease in availability of native habitat. This is probably attributable to the high structural connectivity in the area (sensu Tischendorf \& Fahrig, 2000), with $80 \%$ of the remaining native habitat connected in a single patch. It has been shown that in landscapes with $<50 \%$ of native habitat remaining, connectivity becomes increasingly important for persistence of more sensitive species in the remaining patches (Martensen et al., 2008, 2012). Our results suggest that the persistence of bush dogs in our study area may be attributable to the structural connectivity between patches of native vegetation.

The pack displayed a pattern of rotational use of areas, or semi-nomadic movement (Fig. 1). Information about seasonal movement in mammals is usually associated with seasonal migration (sensu Berger, 2004) between two discrete areas not used at other times of the year. Tropical and temperate ungulates are known to make seasonal migrations associated with changes in water and food supply (Mduma et al., 1999; Ferguson \& Elkie, 2004). Marine mammals (e.g. cetaceans) also migrate seasonally (Mackintosh, 1966; Branch et al., 2007). Wolves Canis lupus are known to follow migratory caribou Rangifer tarandus if abundance of moose Alces 
alces becomes critically low (Ballard et al., 1997). However, to the best of our knowledge yearly rotational movements, such as those reported here and in Lima et al. (2012), have not been reported for any other mammalian species.

The Brazilian Parliament has passed a bill to reduce the percentage of areas to be preserved in private landholdings (Brazilian Conservation Act no. 12.651/2012). Our study indicates this may negatively affect bush dog populations by increasing their spatial requirements. Expansion of the bush dog's home range in human-modified environments may have other negative effects, such as increased exposure to human-related diseases (Jorge et al., 2007a,b; Lima et al., 2009) and lower probability of successful dispersal of subadults. These issues still need to be addressed.

\section{Acknowledgements}

This project was made possible with the help of the Centro Nacional de Pesquisa e Conservação de Mamíferos Carnívoros of the Instituto Chico Mendes de Conservação da Biodiversidade, which provided the necessary permits. All captures and animal handling were carried out in accordance with the code of conduct of The American Society of Mammalogists. We are grateful for the financial support provided by the Conselho Nacional de Desenvolvimento Científico e Tecnológico, Fundação O Boticário de Proteção à Natureza, and Fundação de Amparo à Pesquisa do Estado do Mato Grosso. We thank the field assistants who helped with the collection of data; the veterinarian M.R. Santos for assistance with the capture and handling of animals; Prof. Gualda for technical assistance with IDL programming; the private land owners who helped locate the bush dog pack and allowed us to conduct our research on their properties; and the reviewers for their constructive comments.

\section{References}

Aebischer, N.J., Robertson, P.A. \& Kenward, R.E. (1993) Compositional analysis of habitat use from animal radio-tracking data. Ecology, 74, 1313-1325.

Ballard, W.B., Ayres, L.A., Krausman, P.R., Reed, D.J. \& Fancy, S.G. (1997) Ecology of wolves in relation to a migratory caribou herd in northwest Alaska. Wildlife Monographs, 135, 3-47.

Beasley, J.C. \& Rhodes, O.E. (2010) Influence of patch- and landscape-level attributes on the movement behavior of raccoons in agriculturally fragmented landscapes. Canadian Journal of Zoology, $88,161-169$.

Beisiegel, B.M. (1999) Contribuição ao estudo da história natural do cachorro-do-mato, Cerdocyon thous, e do cachorro-vinagre, Speothos venaticus. In Instituto de Psicologia, Psicologia Experimental, p. 10o. Universidade de São Paulo, São Paulo, Brazil.

Beisiegel, B.M. (2009) First camera trap record of bush dogs in the state of São Paulo, Brazil. Canid News. Http://canids.org/canidnews/ 12/Bush_dogs_in_Sao_Paulo.pdf [accessed 22 May 2014].
BERgER, J. (2004) The last mile: how to sustain long-distance migration in mammals. Conservation Biology, 18, 320-331.

Branch, T.A., Stafford, K.M., Palacios, D.M., Allison, C., Bannister, J.L., Burton, C.L.K. et al. (2007) Past and present distribution, densities and movements of blue whales Balaenoptera musculus in the Southern Hemisphere and northern Indian Ocean. Mammal Review, 37, 116-175.

Cascelli de Azevedo, F.C. \& Murray, D.L. (2007) Spatial organization and food habits of jaguars (Panthera onca) in a floodplain forest. Biological Conservation, 137, 391-402.

Cavalcanti, S.M.C. \& Gese, E.M. (2009) Spatial ecology and social interactions of jaguars (Panthera onca) in the southern Pantanal, Brazil. Journal of Mammalogy, 90, 935-945.

Crawshaw, P.G. \& Quigley, H.B. (1991) Jaguar spacing, activity and habitat use in a seasonally flooded environment in Brazil. Journal of Zoology, 223, 357-370.

DeMatteo, K.E. \& Kochanny, C.O. (2004) Determining an effective and safe radio-tracking collar for bush dogs (Speothos venaticus). Canid News. Http://www.canids.org/canidnews/7/Radiotracking collar_for_bush_dogs.pdf [accessed 22 May 2014].

DeMatteo, K.E. \& Loiselle, B.A. (2008) New data on the status and distribution of the bush dog (Speothos venaticus): evaluating its quality of protection and directing research efforts. Biological Conservation, 141, 2494-2505.

DeMatteo, K., Michalski, F. \& Leite-Pitman, M.R.P. (2011) Speothos venaticus. In IUCN Red List of Threatened Species v. 2012.2. Http://www.iucnredlist.org/ (accessed 2 April 2013].

De Melo, L.F.B., SÁbato, M.A.L., Magni, E.M.V., Young, R.J. \& Coelho, C.M. (2007) Secret lives of maned wolves (Chrysocyon brachyurus Illiger 1815): as revealed by GPS tracking collars. Journal of Zoology, 271, 27-36.

de Oliveira, T.G. (2009) Distribution, habitat utilization and conservation of the Vulnerable bush dog Speothos venaticus in northern Brazil. Oryx, 43, 247-253.

Dietz, J.M. (1984) Ecology and Social Organization of the Maned Wolf (Chrysocyon brachyurus). Smithsonian Institution Press, Washington, DC, USA.

Dietz, J.M. (1985) Chrysocyon brachyurus maned wolf. Mammalian Species, 234, 1-4.

FAHRIG, L. (2003) Effects of habitat fragmentation on biodiversity. Annual Review of Ecology, Evolution, and Systematics, 34, 487-515.

FERGUSON, S.H. \& ElKie, P.C. (2004) Seasonal movement patterns of woodland caribou (Rangifer tarandus caribou). Journal of Zoology, 262, 125-134.

HAYNE, D.W. (1949) Calculation of size of home range. Journal of Mammalogy, 30, 1-18.

ibGe (Instituto Brasileiro de Geografia e Estatística) (2013) Cidades. Http://cidades.ibge.gov.br/xtras/perfil.php?lang= \&codmun $=510020 \&$ search $=$ mato-grosso $\mid \% \mathrm{C}_{3} \% 8$ igua - boa [accessed 15 November 2013].

Jácomo, A.T.D., Kashivakura, C.K., Ferro, C., Furtado, M.M., Astete, S.P., Tôrres, N.M. et al. (2009) Home range and spatial organization of maned wolves in the Brazilian grasslands. Journal of Mammalogy, 90, 150-157.

Jorge, R.S.P., Morato, R.G., Pereira, M., Lima, E.S., Scheffer, K., Carnieli, JR, P. et al. (2007a) Rabies antibodies in a bush dog captured in the Pantanal, Brazil. 56th Annual Wildlife Disease Association Conference, Estes Park, USA.

Jorge, R.S.P., Nunes, C.M., Trinconi, C.M., Paula, H.B., Dias, A. K.K. \& FerReIRA, F. (2007b) Leishmania spp. in wild carnivores captured in the Pantanal, Brazil. 56th Annual Wildlife Disease Association Conference, Estes Park, USA.

Klink, C.A. \& Machado, R.B. (2005) Conservation of the Brazilian Cerrado. Conservation Biology, 19, 707-713. 
Knowlton, J.L. \& Graham, C.H. (2010) Using behavioral landscape ecology to predict species' responses to land-use and climate change. Biological Conservation, 143, 1342-1354.

Lima, E.S., DeMatteo, K.E., Jorge, R.S.P., Jorge, M.L.S.P., Dalponte, J.C., Lima, H.S. \& Klorfine, S.A. (2012) First telemetry study of bush dogs (Speothos venaticus): home range, activity and habitat selection. Wildlife Research, 39, 512-519.

Lima, V.M.F., Fattori, K.R., de Michelin, A.F., Nogueira, F.S. \& DE SouZA, L.O. (2009) Evidence of Leishmania spp. antibodies and DNA in bush dogs (Speothos venaticus) in Brazil. Journal of Zoo and Wildlife Medicine, 40, 91-94.

Mackintosh, N.A. (1966) Distribution of southern blue and fin whales. In Whales, Dolphins, and Porpoises (ed. K.S. Norris), pp. 125-144. University of California Press, Berkeley, USA.

Martensen, A.C., Pimentel, R.G. \& Metzger, J.P. (2008) Relative effects of fragment size and connectivity on bird community in the Atlantic Rain Forest: implications for conservation. Biological Conservation, 141, 2184-2192.

Martensen, A.C., Ribeiro, M.C., Banks-Leite, C., Prado, P.I. \& Metzger, J.P. (2012) Associations of forest cover, fragment area, and connectivity with neotropical understory bird species richness and abundance. Conservation Biology, 26, 1100-1111.

Marzluff, J.M., Millspaugh, J.J., Hurvitz, P. \& Handcock, M.S. (2004) Relating resources to a probabilistic measure of space use: forest fragments and Steller's jays. Ecology, 85, 1411-1427.

Mduma, S.A.R., Sinclair, A.R.E. \& Hilborn, R. (1999) Food regulates the Serengeti wildebeest: a 40-year record. Journal of Animal Ecology, 68, 1101-1122.

Mergey, M., Helder, R. \& Roeder, J.J. (2011) Effect of forest fragmentation on space-use patterns in the European pine marten (Martes martes). Journal of Mammalogy, 92, 328-335.

Michalski, F. (2010) The bush dog Speothos venaticus and short-eared dog Atelocynus microtis in a fragmented landscape in southern Amazonia. Oryx, 44, 300-303.

Michalski, F. \& Peres, C.A. (2007) Disturbance-mediated mammal persistence and abundance-area relationships in Amazonian forest fragments. Conservation Biology, 21, 1626-1640.

Mitchell, M.S. \& Powell, R.A. (2004) A mechanistic home range model for optimal use of spatially distributed resources. Ecological Modelling, 177, 209-232.

MMA (Ministry of the Environment of Brazil) (2003) Instrução normativa, no. 3. In Diário Oficial da União, pp. 88-97. Imprensa Nacional, Brasília, Brazil.

Mohr, C.O. (1947) Table of equivalent populations of North American small mammals. American Midland Naturalist, 37, 223-249.

Nimer, E. (1989) Climatologia do Brasil. IBGE, Departamento de Recursos Naturais e Estudos Ambientais, Rio de Janeiro, Brazil.
Oliveira-Filho, A.T. \& Ratter, J.A. (2002) Vegetation physiognomies and woody flora of the Cerrado biome. In The Cerrados of Brazil: Ecology and Natural History of a Neotropical Savanna (eds P.S. Oliveira \& R.J. Marquis), pp. 91-120. Columbia University Press, New York, USA.

Rabinowitz, A.R. \& Nottingham, B.G. (1986) Ecology and behavior of the jaguar (Panthera onca) in Belize, Central America. Journal of Zoology, 210, 149-159.

Seaman, D.E. \& Powell, R.A. (1996) An evaluation of the accuracy of kernel density estimators for home range analysis. Ecology, 77, 2075-2085.

Sillero-Zubiri, C., Hoffmann, M. \& Macdonald, D.W. (eds) (2004) Canids: Foxes, Wolves, Jackals and Dogs. Status Survey and Conservation Action Plan. IUCN/SSC Canid Specialist Group, Gland, Switzerland, and Cambridge, UK.

Silveira, L., Jácomo, A.T.A., Rodrigues, F.H.G. \& Diniz, J.A.F. (1998) Bush dogs (Speothos venaticus), in Emas National Park, Central Brazil. Mammalia, 62, 446-449.

Tischendorf, L. \& Fahrig, L. (2000) How should we measure landscape connectivity? Landscape Ecology, 15, 633-641.

Tucker, S.A., Clark, W.R. \& Gosselink, T.E. (2008) Space use and habitat selection by bobcats in the fragmented landscape of south-central Iowa. The Journal of Wildlife Management, 72, 1114-1124.

Verbeylen, G., Wauters, L.A., De Bruyn, L. \& Matthysen, E. (2009) Woodland fragmentation affects space use of Eurasian red squirrels. Acta Oecologica, 35, 94-103.

Woodroffe, R. (2011) Ranging behaviour of African wild dog packs in a human-dominated landscape. Journal of Zoology, 283, 88-97.

Worton, B.J. (1987) A review of models of home range for animal movement. Ecological Modelling, 38, 277-298.

Worton, B.J. (1989) Kernel methods for estimating the utilization distribution in home-range studies. Ecology, 70, 164-168.

\section{Biographical sketches}

EDson Lima has been studying bush dogs since 2001. His research interests include ecology, natural history and conservation of canids in the Cerrado and Pantanal. Maria Luisa Jorge has worked on the spatial ecology and conservation of bush dogs since 2008. Her current interests include spatial ecology and conservation of carnivores and ungulates in the Cerrado and Atlantic Forest. Rodrigo Jorge has been studying bush dogs since 2001. His current research interests include disease transmission from domestic to wild carnivores, and conservation of carnivores in Brazil. Ronaldo Morato has been studying bush dogs since 2008 and is interested in the conservation of carnivores in Brazil. 